\title{
ULTRASTRUCTURAL CYTOCHEMISTRY AS A TOOL FOR STUDYING TRANSCRIPTIONAL MECHANISMS
}

\author{
DAVIDE BASELLO $(*)$, BARBARA CISTERNA $(*, * *)$, \\ VALENTINA GALIMBERTI $(*)$, VALENTINA POLETTO $(* * *)$, \\ MARCO BIGGIOGERA $(*, * * * *)$
}

SUNTO. - La citochimica ultrastrutturale è un potente strumento di indagine per l'analisi della biologia del nucleo cellulare. Grazie alla sua elevatissima risoluzione, è stato possibile localizzare con estrema accuratezza i siti di trascrizione, splicing e maturazione sia di RNA messaggero che ribosomale, la loro precisa localizzazione subcellulare e i loro movimenti. Per mezzo di tecniche immunocitochimiche, inoltre, è stato dimostrato per molte proteine nucleari un ruolo specifico nei meccanismi trascrizionali, con la possibilità di mappare la loro presenza su una singola fibrilla di RNA. A partire dagli anni '70, le tecniche ultrastrutturali si sono evolute passando dalla risoluzione dell'autoradiografia a quella degli anticorpi coniugati con oro colloidale, raggiungendo una risoluzione dell'ordine di pochi nanometri. L'utilizzo della microscopia correlativa e della tomografia elettronica ha inoltre permesso l'imaging tridimensionale delle strutture ribonucleoproteiche in situ, nel nucleo. L'associazione di un meccanismo biologico con la localizzazione citochimica di specifiche molecole è stata cruciale per definire l'organizzazione funzionale del nucleo cellulare ed è stata preziosa per la comprensione di molti processi biologici.

$* * *$

(*) Laboratorio di Biologia Cellulare e Neurobiologia, Dipartimento di Biologia e Biotecnologie "Lazzaro Spallanzani", Università di Pavia, Italy.

${ }^{(* *)}$ Dipartimento di Scienze Neurologiche e del Movimento, Sezione di Anatomia e Istologia, Università di Verona, Italy.

${ }^{(* * *)}$ Centro per lo Studio della Mielofibrosi, Laboratorio di Ricerca di Biotecnologia, IRCCS Policlinico San Matteo, Pavia, Italy.

${ }^{(* * * *)}$ E-mail: marco.biggiogera@unipv.it 
ABSTRACT. - Ultrastructural cytochemistry is a powerful tool for investigating the biology of the cell nucleus. Thanks to its very high resolution, it has been possible to localize with extreme accuracy the sites of transcription, splicing and maturation of both mRNA and rRNA, their precise location as well as their movements. By means of immunocytochemical techniques, many nuclear proteins have been given a specific role in the transcriptional mechanisms, with the possibility of precisely mapping their location on a single RNA fibril. Starting from the 70s, the techniques have evolved from the resolution of autoradiography to that of gold-coupled antibodies, reaching a resolution of few nanometers. The use of correlative microscopy techniques as well as of electron tomography has also allowed the 3D imaging of ribonucleoprotein-containing structures in situ, in the nucleus. The association of a biological mechanism with the cytochemical localization of a specific molecule has been crucial in defining the functional organization of the cell nucleus, and has been invaluable for the understanding of many biological processes.

\section{INTRODUCTION}

In the early ' 70 s, the basis for the study and for a deeper understanding of the transcriptional mechanisms were laid by a series of pioneering papers from Wilhelm Bernhard's group. Starting from the first ultrastructural description of the nuclear ribonucleoprotein (RNP) structures (Bernhard, 1969; Monneron and Bernhard, 1969), the use of ultrastructural cytochemistry soon helped to elucidate the nuclear structure and components (Cogliati and Gautier, 1973; Gautier, 1976; Wassef, 1979) as well as its mechanisms (Fakan and Bernhard, 1971; 1973).

Electron microscope (EM) cytochemistry made use, especially at the beginning, of the best tools available at the moment: heavy metal salts, enzymatic techniques, autoradiography. Most of the methods are nowadays only of historical importance, and have been superseded by other means which can give faster answers at higher resolution.

In parallel, the fundamental findings obtained concerning the localization of transcription sites can now be confirmed by the use of cold probes, non-radioactive RNA precursors. Stepping from the silver end-product of autoradiography to colloidal gold-coupled antibodies has allowed a shift from a $40 \mathrm{~nm}$ to $12 \mathrm{~nm}$ resolution in the localization of a given antigen.

Other additional techniques have allowed the selective detection of DNA (Cogliati and Gautier, 1973), DNA and RNA (Derenzini and Farabegoli, 1990) or RNA (Biggiogera and Fakan, 1998). All these techniques can be coupled with immunolabeling and with other meth- 
ods for nucleic acids (see Biggiogera and Fakan, 2008, for a review).

Ultrastructural cytochemistry has been for a long time a major tool in investigating the functional organization of the cell nucleus. While the present methods of light microscopic analysis may give a faster approach and a possibility of three-dimensional visualization, they often give rise to alteration of cellular structure, as shown by subsequent examination by electron microscopy (Visser et al., 2000; Solovei et al., 2002).

\section{WHERE TRANSCRIPTION TAKES PLACE IN THE NUCLEUS}

With a few notable exceptions (see Derenzini et al., 2014), in almost all cells a layer of varying thickness is present at the surface of condensed chromatin at the periphery of the cell nucleus. At this surface, Fakan and coworkers (Albiez et al., 2006) have defined the presence of a 80-100 nm thick layer in which most of the functions of DNA are carried out. Incorporation of cold RNA precursors (Cmarko et al., 1999, 2000; Trentani et al., 2003) have confirmed at higher resolution the localization of transcription phases (Niedioladjo et al., 2011) as well as the co-transcriptional maturation events (splicing, cleavage and polyadenylation, see Cardinale et al., 2007) and of epigenetic factors (Cmarko et al., 2003).

When observed after selective RNA staining, this layer (called Perichromatin Region, PR) is occupied by thin fibrils of variable length, corresponding to the newly synthesized RNA still undergoing maturation, the so-called perichromatin fibrils (PF, Monneron and Bernhard, 1969). These fibrils, in some cases, can be wrapped into $50 \mathrm{~nm}$ granules, the perichromatin granules (PG). The latter can be stored by the cell and then exported, probably by uncoiling in the proximity of the nuclear pore.

In some cases, it is possible to localize the beginning of the transcription and the concomitant presence of a maturation factor on the same fibril (Fig. 1a, b). So far, not even super-resolution microscopy approaches like STED can clearly detect this area and study its mechanisms.

As for the nucleolus, transcriptional activity has been localized (not without some interesting difference of opinion) in a given area of the nucleolus, the dense fibrillar component (see Biggiogera et al., 2001 and Raska et al., 2006 for reviews) surrounding the fibrillar centers. The 
nucleolus represents one of the most interesting structure where EM cytochemistry has been used. Starting from the localization of RNA and DNA (Thiry et al., 1991; Mosgoeller et al., 1993), the search for the actual site of transcription has taken almost a decade, and many different EM techniques have been utilized.
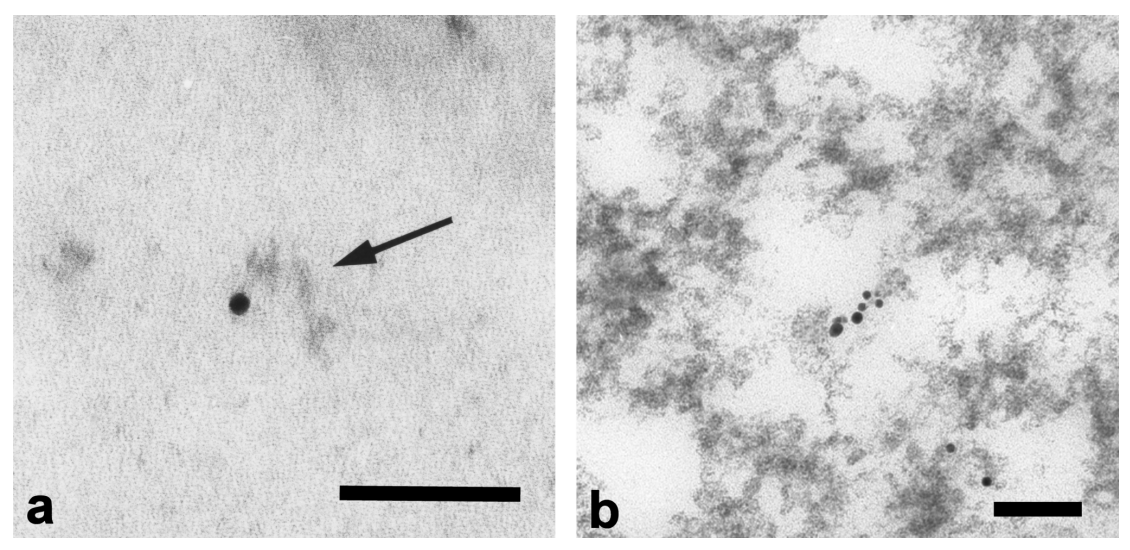

Fig. 1 a) A perichromatin fibril (arrow) is selectively stained for RNA with terbium citrate. The gold grain labels the DNA/RNA bybrid present at the site of the transcription, localizing in this way the starting point of the fibril. Bar=50 nm (reproduced by permission from Trentani et al., 2003); b) Multiple labelling on the same nascent fibril: the small $(6 \mathrm{~nm})$ gold grains label the incorporated RNA precursor bromouridine, the $12 \mathrm{~nm}$ are linked to the cleavage factor CFI and the $18 \mathrm{~nm}$ to the polyadenylation factor CstF. Bar=50 nm.

\section{MOVEMENTS AND EXPORT OF RNAS}

RNA must be displaced from the PR and moved towards the pore. This movement has always been considered as due to a diffusion process mechanism (Politz et al., 1999; 2003); however, we have shown that a part of the export mechanism of the small ribosome subunit is an active one (Cisterna et al., 2006, 2009) and can be partially inhibited by affecting ATP synthesis. Moreover, actin and nuclear myosin seem to be involved in this process. As for mRNA, we are currently studying the role of these proteins and ATP in the movements of PF (Basello et al., submitted). Our preliminary results indicate that ATP is required to move the PF if and when it becomes stuck on the surface of condensed chromatin. 
As for RNA migration toward the nuclear pore, most of these molecules will be exported in a short time, while some will be retained as storage. By incubating proliferating cells with RNA precursors, it is possible also to have an idea of the export rate in control cells when compared with cells treated with drugs inducing metabolic stasis. Still unclear is whether the PF is the only form of processed RNA to be "routinely" used for export, since so far it is not known the frequency and the composition of the RNAs which are converted into PG. RNA export, in any case, is carried out also with an exchange, occurring near the nuclear pore, of the proteins involved in the movement of the RNP (Cisterna et al., 2006).

Movements of RNAs necessarily involve the movements of proteins. For instance, the use of proteasome inhibitors (PI) induces endoplasmic reticulum stress, reduction of transcription and translation for few specific mRNAs, together with nuclear mRNA processing and transport interference (Casafont et al. 2010). DRG neurons treated with the PI Bortezomib show a reorganization of poly-adenylated RNAs in both nuclear and cytoplasmic sub-structures. Nucleolus is also influenced by PI treatment, and several nuclear proteins related to the stress response (such as Hsp70, PML, p53, MDM2) has been shown to translocate into the nucleolus (Klibanov et al. 2001; Karni-Schmidt et al. 2008; Latonen et al. 2003). An example is given by ATF-4, a transcription factor which has been recently shown to shuttle from the cytoplasm to the nucleus and finally to the dense fibrillar and granular components of the nucleolus after PI treatment (Galimberti et al. in preparation). During this event, ATF4 interacts with RNA and it may prevent pre-rRNA maturation and consequently the ribosomal subunits biogenesis (Galimberti, 2015).

\section{CONVERTIBLE TECHNIQUES}

Electron microscopy can take advantage also from the conversion of techniques originally devised for light microscopy. In particular, during the last years a simple technique providing the "translation" of fluorescent molecules into electrondense final products has been developed. The emission light of the excited fluorochrome can induce the precipitation of diaminobenzidine $(\mathrm{DAB})$ in the precise spot where the former is present. DAB can eventually be rendered even more electron- 
dense by osmium tetroxide. In this way it is possible to observe the same specimen at two levels of resolution as correlative microscopy. We have made use of this technique to localize fluorescein-loaded nanoparticles (Malatesta et al., 2012; 2014) as well as for the localization of calcium ions in the cytoplasm (Poletto et al., 2015). Moreover, calcium ions can be also found in the nucleus, as already shown by Tandler et al. (1970). However, the methodology used in this pioneering paper did not allow a high resolution of the $\mathrm{Ca}^{++}$localization. On the contrary, the use of a specific, fluorescent $\mathrm{Ca}$-binding probe rendered electrondense allows the fine structural detection of this element in the PR area, thus suggesting a role of $\mathrm{Ca}^{++}$in the transcription/maturation machinery (Poletto et al., in preparation).

\section{STILL UNSOLVED}

The functional architecture of the cell nucleus has been studied for more than four decades. Nevertheless, there are still unsolved relationships between structure and function. One example is the role played by the space in the nucleus not occupied by chromatin, nucleolus or nuclear bodies. This space, called interchromatin space (IS) is far from being empty and hosts a lot of different functions and events. Among these, the movements of proteins and RNAs occur here, and the machinery involved must be therefore present. The traffic by diffusion or by active mechanisms must therefore be remarkable, considering all the molecules involved; nevertheless there is no interference, but on the contrary some preferential lanes can be sometimes observed. PF (and probably PG) move essentially in a peripheral lane (near the surface of chromatin) while nuclear bodies are present essentially in the more central open space. These components, in fact, utilize the IS as a sort of channel toward their destination (another part of the nucleus or export). It would be interesting to find if preferential lanes are due to a passive mechanism or are regulated by some unknown factor(s).

\section{THE FUTURE}

A possible major role in the study of transcription at the ultrastructural level could be played by the combined use of several tech- 
niques. Electron tomography has been used for several high resolution studies such as in the case of Balbiani ring granules (Lönnroth et al., 1992), giving the opportunity to visualize a $3 \mathrm{D}$ image of the structures. However, it would be possible to make use of specific photoconverted probes to visualize not a single structure but a biological process from the beginning of RNA synthesis to cleavage and movement. A final 3D image with the resolution of electron microscopy will be a further step in understanding the functional architecture of the nucleus.

\section{CONCLUDING REMARKS}

EM cytochemistry is a powerful tool in the analysis of the functional architecture of the cell nucleus. The possibility of combining different approaches allows to follow dynamic processes and to determine, at the same time, the chemical nature of the structural constituents. Although reaching only two-dimensional imaging, the high resolution of electron microscopic methods makes them invaluable complement to any type of light microscopic visualization. This is especially important when one carries out parallel analysis by light microscopy in vivo where the same cell, first recorded by fluorescence microscopy using vital fluorochromes, can then be analyzed by methods of EM cytochemistry. This new approach avoids harsh treatments and artifacts occurring during different light microscopic labeling protocols and opens certainly a new avenue in cell biology. The diversity of EM preparative procedures offers the microscopist a wide choice of methodological approaches, without which light microscopic observations often remain only indicative.

\section{ACKNOWLEDGEMENTS}

The authors would like to thank Ms. Francine Flach for the excellent technical expertise and Dr. Irene Masiello for critical reading of the manuscript. 


\section{REFERENCES}

Albiez H, Cremer M, Tiberi C, Vecchio L, Schermelleh L, Dittrich S, et al. Chromatin domains and the interchromatin compartment form structurally defined and functionally interacting nuclear networks. Chromosome Res 2006;14:707-33.

Bernhard W. A new staining procedure for electron microscopical cytology. J Ultrastruc Res 1969; 27:250-65.

Biggiogera M, Fakan S. Visualization of nuclear organization by ultrastructural cytochemistry. Methods Cell Biol 2008;88:431-49.

Biggiogera M, Fakan S. Fine structural specific visualization of RNA on ultrathin sections. J Histochem Cytochem 1998; 46: 389-95.

Biggiogera M, Malatesta M, Abolhassani-Dadras S, Amalric F, Rothblum LI, Fakan S. Revealing the unseen: the organizer region of the nucleolus. J Cell Sci 2001;117: 3199-3205.

Cardinale C, Cisterna B, Bonetti P, Aringhieri C, Biggiogera M, Barabino SML. Subnuclear localization and dynamics of the pre-mRNA 3' end processing factor CF Im68. Mol Biol Cell, 2007;18: 1282-92.

Casafont I, Berciano MT, Lafarga M. Bortezomib induces the formation of nuclear poly (A) RNA granules enriched in Sam68 and PABPN1 in sensory ganglia neurons. Neurotox Res 2010;17:167-78.

Cisterna B, Malatesta M, Dieker J, Muller S, Prosperi E, Biggiogera M. An active mechanism flanks and modulates the export of the small ribosomal subunits. Histochem Cell Biol 2009;131: 743-753.

Cisterna B, Necchi D, Prosperi E, Biggiogera M. Small ribosomal subunits associate with nuclear myosin and actin in transit to the nuclear pores. Faseb J 2006; 20:1901-03.

Cmarko D, Verschure PJ, Martin TE, Dahmus ME, Krause S, Fu XD, et al. Ultrastructural analysis of transcription and splicing in the cell nucleus after bromo-UTP microinjection. Mol Biol Cell 1999;10:211-23.

Cmarko D, Verschure PJ, Otte AP, van Driel R, Fakan S. Polycomb group gene silencing proteins are concentrated in the perichromatin compartment of the mammalian nucleus. J Cell Sci 2003;116:335-43.

Cmarko D, Verschure PJ, Rothblum LI, Hernandez-Verdun D, Amalric F, et al. Ultrastructural analysis of nucleolar transcription in cells microinjected with 5bromo-UTP. Histochem Cell Biol 2000;113:181-7.

Cogliati R, Gautier A. Mise en évidence de l'ADN et des polysaccharides à l'aide d'un nouveau réactif "de type Schiff". CR Acad Sci 1973; 276:3041-44.

Derenzini M, Farabegoli F. Selective staining of nucleic acids by osmium ammine complex in thin sections from Lowicryl-embedded samples. J Histochem Cytochem 1990;28:1495-501.

Derenzini M, Olins AL, Olins DE. Chromatin structure in situ: the contribution of DNA ultrastructural cytochemistry. Eur J Histochem. 2014;58:2307. doi: 10.4081/ejh. 2014.2307.

Fakan S, Bernhard W. Localization of rapidly and slowly labelled nuclear RNA as visualized by high resolution autoradiography. Exp Cell Res 1971; 67:129-41. 
Fakan S, Bernhard W. Nuclear labelling after prolonged 3H-uridine incorporation as visualized by high resolution autoradiography. Exp Cell Res. 1973;79:431-44.

Galimberti V. ATF4: a protein unexpectedly shuttling to nucleoli after Bortezomib treatment. Ph.D. Thesis, 2015, University of Pavia, pp.1-109.

Gautier A. Ultrastructural localization of DNA in ultrathin tissue sections. Int Rev Cytol 1976;44:113-91. J Ultrastruct Res. 1969;27:266-88.

Karni-Schmidt O, Zupnick A, Castillo M, Ahmed A, Matos T, Bouvet P, et al. p53 is localized to a sub-nucleolar compartment after proteasomal inhibition in an energy-dependent manner. J Cell Sci 2008;121:4098-4105.

Klibanov SA, O'Hagan HM, Ljungman M. Accumulation of soluble and nucleolar-associated 553 proteins following cellular stress. J Cell Sci 2001;114:1867-73.

Latonen L, Kurki S, Pitkänen K, Laiho M. 553 and MDM2 are regulated by PI-3-kinases on multiple levels under stress induced by UV radiation and proteasome dysfunction. Cell Signal 2003;15:95-102.

Lönnroth A, Alexciev K, Mehlin H, Wurtz T, Skoglund U, Daneholt B. Demonstration of a 7-nm RNP fiber as the basic structural element in a premessenger RNP particle. Exp Cell Res 1992;199:292-6.

Malatesta M, Giagnacovo M, Costanzo M, Conti B, Genta I, Dorati R, et al. Diaminobenzidine photoconversion is a suitable tool for tracking the intracellular location of fluorescently labelled nanoparticles at transmission electron microscopy. Eur J Histochem 2012;56:e20. doi: 10.4081/ejh.2012.20.

Malatesta M, Pellicciari C, Cisterna B, Costanzo M, Galimberti V, Biggiogera M, et al. Tracing nanoparticles and photosensitizing molecules at transmission electron microscopy by diaminobenzidine photo-oxidation. Micron 2014;59: 44-51.

Monneron A, Bernhard W. Fine structural organization of the interphase nucleus in some mammalian cells.

Mosgöller W, Schöfer C, Derenzini M, Steiner M, Maier U, Wachtler F. Distribution of DNA in buman Sertoli cell nucleoli. J Histochem Cytochem 1993;41:1487-93.

Niedojadlo J, Perret-Vivancos C, Kalland KH, Cmarko D, Cremer T, van Driel R, et al. Transcribed DNA is preferentially located in the perichromatin region of mammalian cell nuclei. Exp Cell Res 2011;317:433-44.

Poletto V, Galimberti V, Rosti V, Moccia F, Biggiogera M. Fine structural detection of calcium ions py photoconversion. 2015; Submitted.

Politz J, Tuft R, Pederson T, Singer R. Movement of nuclear poly (A) RNA throughout the interchromatin space in living cells. Current Biology 1999;9: 285-91.

Politz JC, Tuft RA, Pederson T. Diffusion-based transport of nascent ribosomes in the nucleus. Mol Biol Cell 2003;14: 4805-12.

Raska I, Shaw PJ, Cmarko D. Structure and function of the nucleolus in the spotlight. Curr Opin Cell Biol 2006;18, 324-34.

Solovei I, Cavallo A, Schermelleh L, Jaunin F, Scasselati C, Cmarko D, et al. Spatial preservation of nuclear chromatin architecture during three-dimensional fluorescence in situ bybridization (3D-FISH). Exp Cell Res 2002;276:10-23.

Tandler CJ, Libanati CM, Sanchis CA. The intracellular localization of inorganic cations 
with potassium pyroantimonate. Electron microscope and microprobe analysis. J Cell Biol 1970;45:355-66.

Thiry M, Scheer U, Goessens G. Localization of nucleolar chromatin by immunocytochemistry and in situ bybridization at the electron microscopic level. Electron Microsc Rev 1991;4:85-110.

Trentani A, Testillano PS, Risueño MC, Biggiogera M. Visualization of transcription sites at the electron microscope. Eur J Histochem 2003;47:195-200.

Visser AE, Jaunin F, Fakan S, Aten JA. High resolution analysis of interphase chromosome domains. J Cell Sci 2000;113:2585-93.

Wassef M. A cytochemical study of interchromatin granules. J Ultrastruct Res 1979;69:121-33. 